\title{
Assessment of Undiscovered Sandstone-Hosted Uranium Resources in the Texas Coastal Plain, 2015
}

The U.S. Geological Survey estimated a mean of 220 million pounds of recoverable uranium oxide $\left(U_{3} O_{8}\right)$ remaining as potential undiscovered resources in southern Texas. This estimate used a geology-based assessment method for Tertiary sandstone-hosted uranium deposits in the Texas Coastal Plain sedimentary strata (fig.1).

\section{Introduction}

The United States is the world's largest consumer of uranium used in nuclear power plants, which provide approximately 19 percent of the Nation's electricity. More than 90 percent of the uranium used domestically to generate nuclear power is imported (U.S. Department of Energy, 2015). Assessment of undiscovered domestic uranium resources is a critical component of a sustainable nuclear industry in the United States.

In 2015, the U.S. Geological Survey (USGS) completed an assessment of undiscovered uranium resources hosted by Tertiary sedimentary sequences of the Texas Coastal Plain. These deposits are found in sandstones, which are the most prolific uranium deposits in the United States. Deposits in the Texas Coastal Plain region are estimated to contain the third largest domestic sandstone-hosted uranium resource after the Colorado Plateau and Wyoming Basin regions.

Estimates of undiscovered uranium resources associated with sandstonehosted deposits in the Texas Coastal Plain were made for geologic units with known uranium occurrences: the Eocene Claiborne and Jackson Groups, the Oligocene Catahoula Formation, the Miocene Oakville Sandstone, the Pliocene Goliad Sand and Willis Formation, and the Pleistocene Lissie Formation (fig. 1). Sandstone facies that host mineralization were deposited in mixed marine-coastal-fluvial facies (Claiborne and Jackson Groups) and by dominantly fluvial systems (Catahoula
Formation, Oakville Sandstone, Goliad Sand, Willis and Lissie Formations). Uranium exploration is active throughout the region, and the Goliad Sand is host to two operating, in situ recovery mines, Alta Mesa and La Palangana (fig. 1).

\section{Assessment Methodology}

The USGS assessment methodology, the three-part form, uses known uranium mineral site locations and deposit resources in combination with associated geologic features to estimate numbers of undiscovered deposits and to identify regions that may host them. The method includes (1) delineation of geographic regions (tracts) that are permissive for the occurrence of deposits as guided by known deposits and a descriptive mineral deposit model, (2) probabilistic estimation of numbers of undiscovered deposits within each permissive tract, and (3) calculation of the probable amount of undiscovered uranium based on the estimated number of undiscovered deposits and grade-tonnage models of known deposits in the region using Monte Carlo simulation (Singer and Menzie, 2010).

There are at least 169 identified mineral sites in the region that have produced in total approximately 81 million pounds of uranium oxide $\left(\mathrm{U}_{3} \mathrm{O}_{8}\right)$ with reported in-place (unmined) uranium resources of about 59 million pounds of $\mathrm{U}_{3} \mathrm{O}_{8}$. Ore bodies typically are narrow and long, with strike lengths ranging from meters to kilometers. In order to establish a uniform and consistent definition for a uranium deposit, individual mineral sites within the same ore body were grouped.
Geologic sedimentary units known to host uranium deposits were used to delineate three permissive tracts: (1) the Claiborne-Jackson tract, (2) the Catahoula-Oakville tract, and (3) the Goliad-Willis-Lissie tract (table 1). The tracts group stratigraphic sequences that were deposited in broadly similar depositional environments. The tracts were geographically subdivided into the Rio Grande Embayment sub-tract (the southwestern region with more known occurrences and higher mineral potential) and the Houston Embayment sub-tract (the northeastern region with less known occurrences and lower mineral potential), forming a total of six sub-tracts (fig. 2).

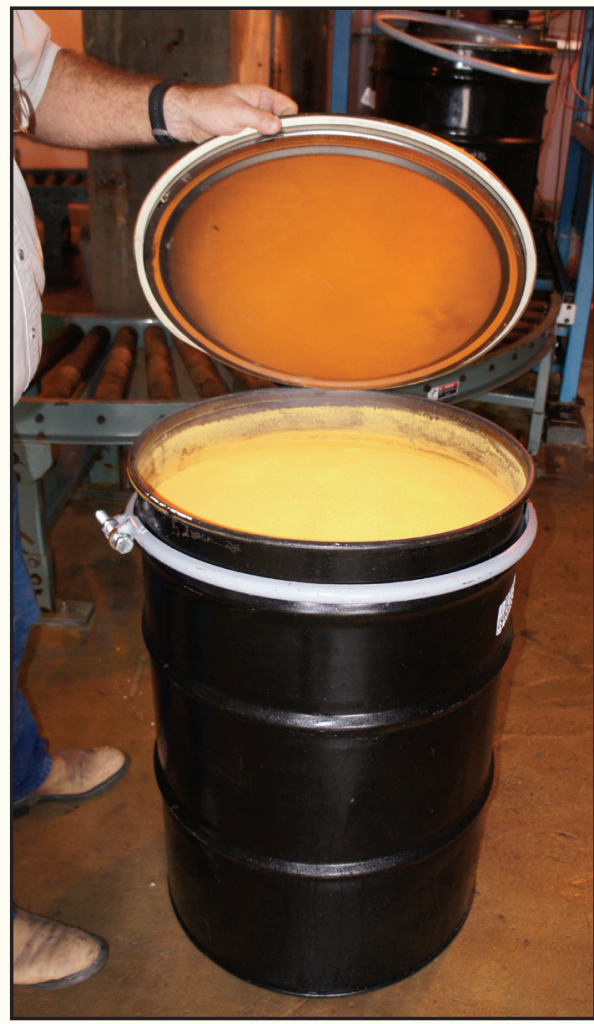

Fifty-gallon barrel containing uranium oxide $\left(\mathrm{U}_{3} \mathrm{O}_{8}\right)$, or yellowcake, produced by the Hobson Processing Plant in southern Texas. (Photo used with permission from Uranium Energy Corporation.) 


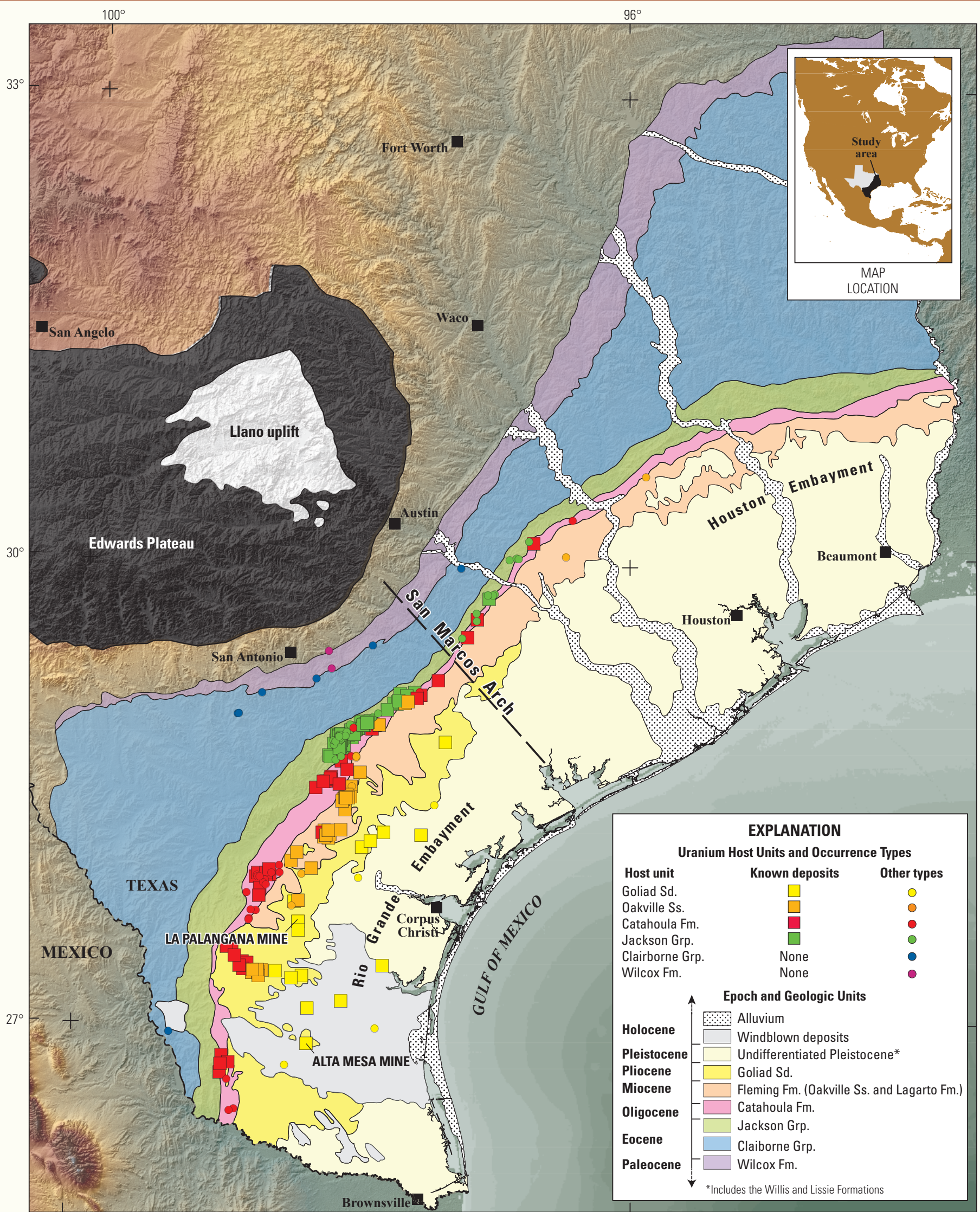

Base from National Geophysical Data Center (NGDC), ETOP01 1 Arc-Minute Global Relief Model,

http://www.ngdc.noaa.gov/mgg/global/;

Projection is U.S.A. Continuous Albers Equal Area Conic

Central meridian $-96^{\circ} \mathrm{E}$, Latitude of origin $37.5^{\circ}$

North American Datum of 1983;

Political boundary from Texas Parks and Wildlife Department,

https://tpwd.texas.gov/gis/data/downloads, September 2015

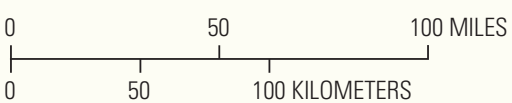

Geology from Schruben and others, 1994 
Table 1. Assessment results for identified and undiscovered uranium resources in sandstone-hosted uranium deposits, Texas Coastal Plain.

[The tracts are arranged in stratigraphic order, from oldest (Claiborne-Jackson Tract) to youngest (Goliad-Willis-Lissie Tract). RE, Rio Grande Embayment; HE, Houston Embayment; $\mathrm{km}^{2}$, square kilometers; area, area of permissive tract in square kilometers; $N_{\text {known }}$, number of known deposits in the tract that have identified resources (deposits represent grouped occurrences, as explained in the fact-sheet); $N_{\text {und }}$, expected number of undiscovered deposits; $\mathrm{U}_{3} 0_{8}$, uranium oxide; lbs, pounds. Undiscovered resources are reported to two significant figures; numbers may not add up because of rounding. The permissive area is inclusive of the favorable and prospective areas. $N_{\text {und }}$ is calculated using a regression equation (Singer and Menzie, 2010). Identified uranium resources include produced (mined) and in-place resources; undiscovered resources are calculated as recoverable not in-place. Undiscovered resources are calculated by combining probabilistic estimates of numbers of undiscovered deposits with a custom grade and tonnage model using Monte Carlo simulation (Root and others, 1991). See Singer and Menzie (2010) for an explanation of quantitative mineral resource assessment methods]

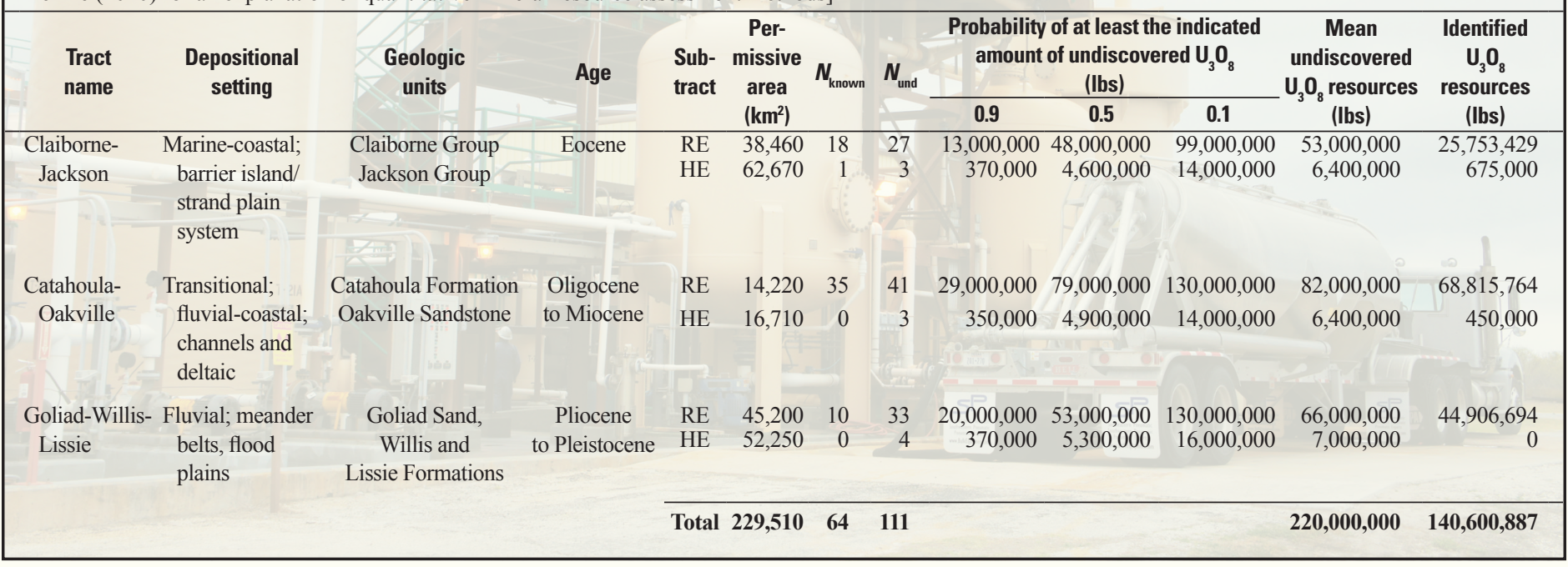

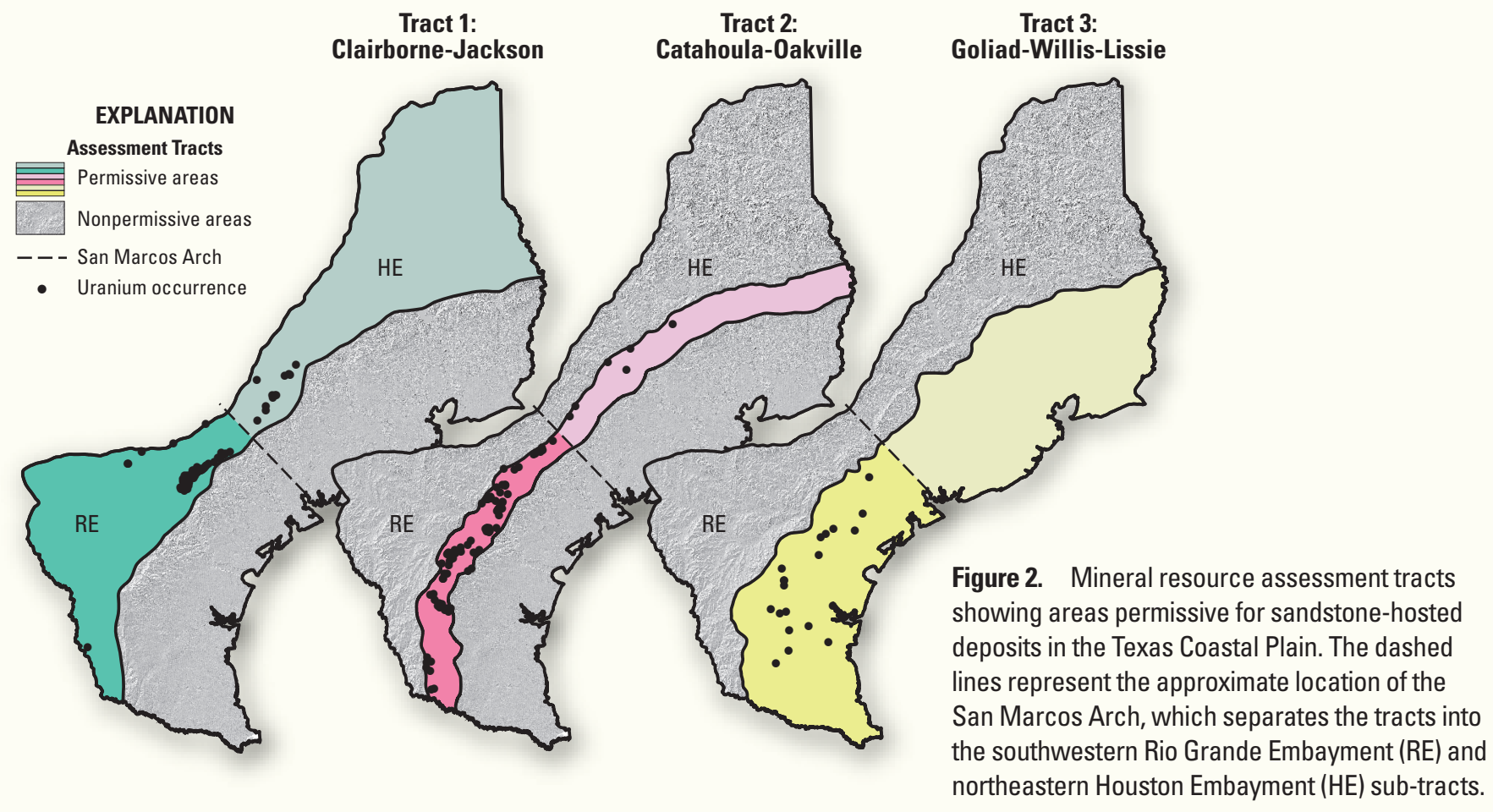

Figure 1 (facing page). Generalized geologic map of the southern Texas Coastal Plain showing operating mines and known uranium occurrences symbolized by their host geologic unit (color) and type (size and shape). Deposits represent mineral sites with recorded uranium production and (or) identified resources. Other types of uranium occurrences include prospects (sites that have some level of exploration), showings (sites of interest that have been recorded), and anomalies (sites with indications that mineralizing processes may have taken place). The region is subdivided by the San Marcos Arch, a broad southeast-trending geologic feature that influenced the deposition and subsequent subsidence of Jurassic through Miocene strata. 
Within each sub-tract, undiscovered resources were assessed to a depth of 1,500 feet ( $\sim 50$ meters). Although most uranium mining has taken place at depths less than 800 feet ( $\sim 240$ meters), economic deposits have been identified to depths of more than 1,200 feet ( $\sim 365$ meters); therefore, 1,500 feet ( $\sim 450$ meters) is the practical depth for the purposes of uranium mineral resource assessment in the region at this time.

\section{Undiscovered Resource Summary}

A mean estimate of 220 million pounds of undiscovered, recoverable $\mathrm{U}_{3} \mathrm{O}_{8}$ encompassing all six permissive sub-tracts in the Texas Coastal Plain represents nearly 1.6 times the amount of uranium that has already been identified and (or) produced from the region (table 1). The Rio Grande Embayment sub-tract region has the largest estimated undiscovered resource, with a calculated mean total of 200 million pounds of undiscovered $\mathrm{U}_{3} \mathrm{O}_{8}$, whereas the Houston Embayment sub-tract region is estimated to host a mean of 20 million pounds of $\mathrm{U}_{3} \mathrm{O}_{8}$. Among the six tracts, the Catahoula-Oakville tract, as a whole, has the largest estimated undiscovered resource (calculated mean total of 88 million pounds $\mathrm{U}_{3} \mathrm{O}_{8}$ ), followed by the Goliad tract (73 million pounds of $\mathrm{U}_{3} \mathrm{O}_{8}$ ) and the Claiborne-Jackson tract ( 59 million pounds of $\mathrm{U}_{3} \mathrm{O}_{8}$ ).

In 2014, U.S. utilities purchased 53 million pounds of $\mathrm{U}_{3} \mathrm{O}_{8}$ for use in civilian nuclear power reactors (U.S. Department of Energy, 2015). Based on these data, the current identified in-place resource represents about 1 year of U.S. nuclear fuel requirements. If found and produced, the undiscovered resources of the Texas Coastal Plain may satisfy roughly another 4 years of domestic requirements.

\section{References}

Root, D.H., Menzie, W.D., and Scott, W.A., 1992, Computer Monte Carlo simulation in quantitative resource estimation: Natural Resources Research, v. 1, no. 2, p. 125-138.

Schruben, Paul G., Arndt, Raymond E., Bawiec, Walter J., King, Philip B., and Beikman, Helen M., 1994, Geology of the conterminous United States at 1:2,500,000 scaleA digital representation of the 1974 P.B. King and H.M. Beikman map: U.S. Geological Survey Digital Data Series DDS-11, Release 2, accessed September 2015, at http://pubs.usgs.gov/dds/dds11/.

Singer, D.A., and Menzie, W.D., 2010, Quantitative mineral resource assessments - An integrated approach: New York, Oxford University Press, 232 p.

U.S. Department of Energy, 2015, 2014 Uranium Marketing Annual Report: U.S. Energy Information Administration, 70 p., accessed July 2015, at http:/www.eia.gov/uranium/marketing/.

\section{Additional Information}

Supporting geologic studies of the Texas Coastal Plain region are available at http://energy.usgs.gov/ OtherEnergy/Uranium.aspx. Documentation about the USGS mineral resource assessment method is available at http://minerals.usgs.gov/global/, http://pubs.usgs.gov/of/2001/ of01-291/ and http://pubs.usgs.gov/bul/b2218/.

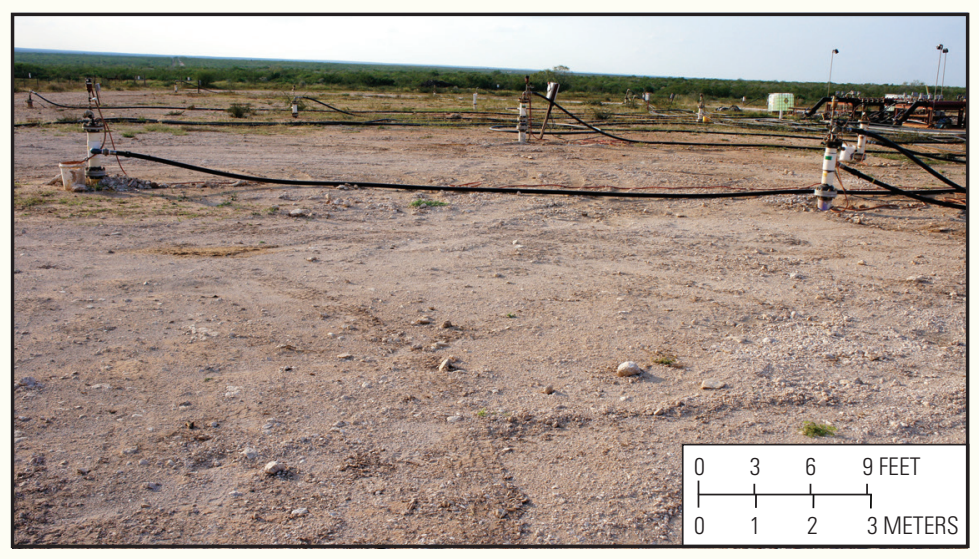

Injection and recovery wells at the La Palangana in situ recovery uranium mine, Duval County, Texas. (Photo used with permission from Uranium Energy Corporation.)



Outcrop of the Oligocene Catahoula Formation, which is largely composed of volcanic ash that may be an important source of uranium for the deposits of the Texas Coastal Plain.

\section{Assessment Team}

U.S. Geological Survey: Mark J. Mihalasky, Susan M. Hall, Jane M. Hammarstrom, Kathleen R. Tureck, Mark T. Hannon, George N. Breit, and Robert A. Zielinski. Texas Bureau of Economic Geology: Brent Elliott.

\section{Contact Information}

$$
\begin{gathered}
\text { Mark Mihalasky } \\
\text { mjm@usgs.gov } \\
\text { (509) 368-3118 } \\
\text { Susan Hall } \\
\text { susanhall@usgs.gov } \\
\text { (303) 236-1656 }
\end{gathered}
$$

